10) Puck, T. T., Garen, A. and Cline, J. : The mechanism of virus attachment to host cells. I. The role of ions in the primary reaction. J. Expp. Med., 98，65-88，1951. 11) 新眺正男：日本脳炎

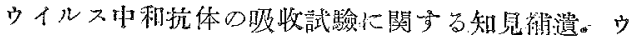
イルス, 2, 12-19, 1952. 12) Delbrïck, M. :The growth of bacteriophage and lysis of the host. $J$. Gen. Physiol, 23, 643-660, 1940. - 13) Barry, G. T. and Goebel, W.F. : The effect of chemical and physical agents on the prage receptor of phase II Shigella sonnei. J. Exp. Med., 94, 387-400, 1951.

\title{
バクテリオファージミ溶菌残沮この可逆的結合 $(\mathbb{I})$
}

塩類の影響，並びにファージ一加熱死菌結合との比較

内田清二郎 *

\section{SEIJIRO UCHIDA : REVERSIBLE ATTACHMENT BETWEEN BACTERIOPHAGE AND BACTERIAL DEBRIS (II) \\ [受稿３月23日 1955]}

\section{ま元がき}

前報ではファージが溶囷残㨊と結合して不活化する こと、この結合は加温によつてはなれ、ファージは再 び活性となることを述べた。本赤でこの結合に2,3 の塩類が影響卞ること学報告したい。文フファーシと 残渣が結合寸るのは，菌のファージレセプタ一务残渣 飞残つているためではないかと考它られるが、尼しそ らならファージの菌への吸厚は、ファージの残㴡への

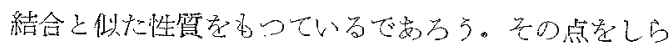
ベるために行つたファージ一加熱死蒠結合の解離の実

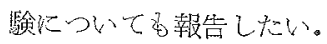

\section{材料之方法}

\section{囷、ファァージ及びファージ保痛液}

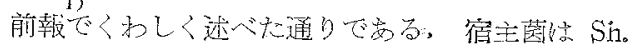
dysenteriae, type II, 府中株, ファージは P7.ファー

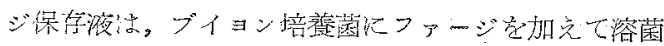
己娃た液を $63^{\circ} \mathrm{C}$ ，10分加温した後，10,000 R.P.M.20

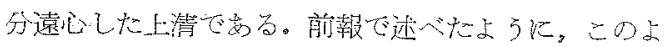
うにしてつくられた保存液には，始めは残溘之結合し ているファージは存在していないが, 保存 1 週間頃か ら段々に残渣との結合によるファージ拪の下降が目

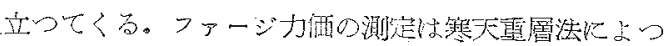
t心.

\section{試薬と使用器具の清洗}

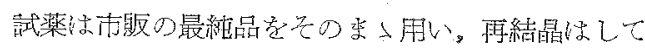
いない。蒸溜水は全部ガラスからなる装置で再蒸溜し たもの孛つかつた。試歌管ピペットはクロム硫酸に

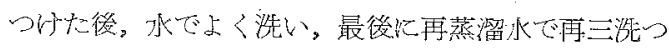
$\approx$

\section{実 験 結 果}

\section{1. 予備害験一塩類溶液中でのファージの安定性一}

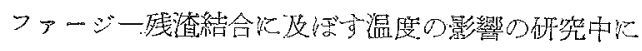

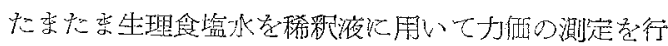
つたところっブイョンを稀称液として測つた洒より高

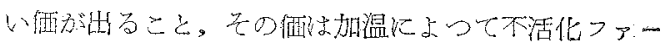
ジを活性化した時の洒と大体一致することにきづい た。このことは，生琶食塩水の中で陡ファージと残浡 の結合が維持されないて離れてし季うこと孝意味して

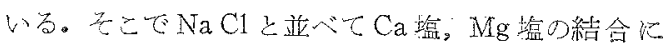
仪に゙す影響をしらベたいと考党たが，その前れ，之等 の溶液中でのファージの㚣定性を知る必要が岁る。第 1表に示すよに、つくりたてのファージ保存液堂ブ

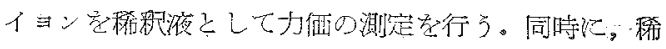
彩した液を $50^{\circ} \mathrm{C} 5$ 分加温してからら平板心委く。1 $10^{\circ}$ 倍

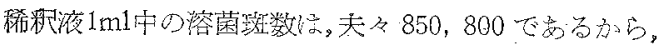
この保存液のファージ力洒は $8.5 \times 10^{8} / \mathrm{m} 1$ でる。，ま た宁定通り、この保存液中炕は残渣と加温によつて離

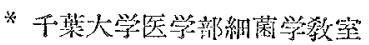




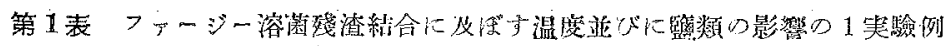

\begin{tabular}{|c|c|c|c|c|c|c|c|c|c|c|}
\hline 稀 秎 液 & ブ 1 & $1 \exists=$ & 蒸 流 & 水 & $0.1 \mathrm{Mo}$ & $1 \mathrm{NaCl}$ & $0.01 \mathrm{Mc}$ & $1 \mathrm{CaCl}_{2}$ & $0.01 \mathrm{Mol}$ & $\mathrm{Mg} \mathrm{SO} 4$ \\
\hline 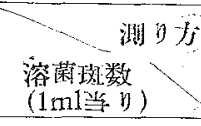 & 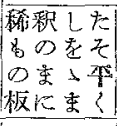 & 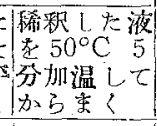 & その要1 & 加 温 & そのま小 & 加 温 & そのまゆ & 加 温 & そのま & 加 温 \\
\hline $\begin{array}{l}\text { つりたてのフ } \\
\text { アージ保存液 }\end{array}$ & 850 & 800 & 930 & 0 & 860 & 0 & 820 & 570 & 840 & 630 \\
\hline $\begin{array}{l}\text { 同上液を } 2 \text { ヶ月 } \\
\text { 間保存した它の }\end{array}$ & 94 & 700 & 790 & 0 & 650 & 0 & 100 & 120 & 480 & 560 \\
\hline
\end{tabular}

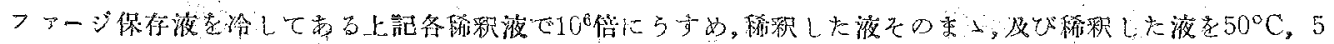

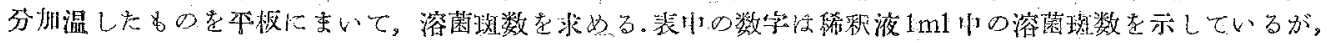

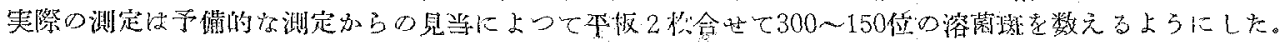

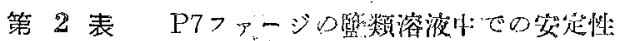

\begin{tabular}{|c|c|c|c|c|c|c|c|c|c|}
\hline 溶液㠜数 & 稀 彩 液 & 蒸 & 溜 & 水 & $0.1 \mathrm{Mol}$ & $\mathrm{aCl}$ & $0.01 \mathrm{Mol}$ & $\mathrm{aCl}_{2}$ & $0.01 . \mathrm{Mol} \mathrm{MgSO}_{4}$ \\
\hline $\begin{array}{r}\text { * } \\
\text { 稀积直後 }\end{array}$ & $\begin{array}{c}\text { 各実噞值 } \\
\text { 本 均 }\end{array}$ & 110, & $\begin{array}{l}51 \\
85\end{array}$ & 93 & $\begin{array}{c}100, \quad 100 \\
98\end{array}$ & 95 & $\begin{array}{c}97, \quad 108, \\
98\end{array}$ & 89 & $90, \quad \begin{array}{rr}* 9 * & 112 \\
100 & \end{array}$ \\
\hline $\begin{array}{l}50^{\circ} \mathrm{C} 5 \text { 分 } \\
\text { 扠 温 後 }\end{array}$ & $\begin{array}{c}\text { 各実驗值 } \\
\text { 督均 }\end{array}$ & 0 & $\begin{array}{l}0 \\
7\end{array}$ & 21 & $\begin{array}{l}0 \\
0 .\end{array}$ & 0 & $\begin{array}{c}70, \quad 66, \\
73\end{array}$ & 82 & $69, \quad 75,100$ \\
\hline
\end{tabular}

*ブィヨンで稀釈した時の溶菌斑擞を 100 とした時の数になおしてある。

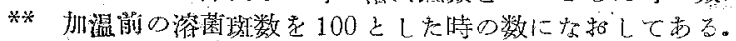

*** $0.01 \mathrm{Mol} \mathrm{Mg} \mathrm{Cl} \mathrm{M}_{2}$ 娄稀瀵液に用w卡侧。

れるような可这的結合をしているファージは存在して いない豪及雅められた。この保存液老分されている蒸 溜水, $0.1 \mathrm{Mol} \mathrm{NaCl}, 0.01 \mathrm{Mol} \mathrm{Ca} \mathrm{Cl}_{2}, 0.01 \mathrm{Mol} \mathrm{Mg}$ $\mathrm{SO}_{4}$ の各溶液で $10^{6}$ 倍に稀䣋した時火は，元の $1 \mathrm{~m} 1$ 当

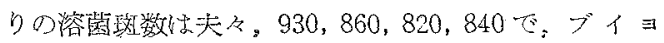
ンでの洒之摆差簕囲で致している。彷つてこれらの 液では，低温で希㔄している間以ファージが不活化さ れるよらなことはないことがわかりた。次にこれらの

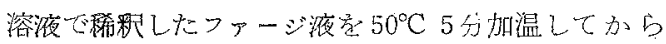

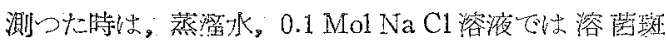
は出現せず，0.01 Mol Ca Cl, $0.01 \mathrm{Mol} \mathrm{Mg} \mathrm{SO} 4$ 溶液 では、加温しなかた蛙の数の天々，70パーセント，75 パーセントに減少している。同様な実䜺をくりかえし

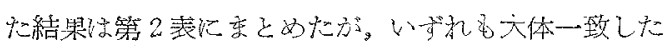
結祭を示している。たざ蒸溜永の場合，稀彩したたけ で半墄している例，奴び $50^{\circ} \mathrm{C} 5$ 分加温しても21パセントのファージが残つた例が市る。これらは，蒝溜

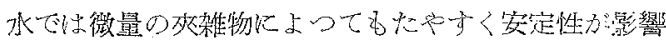
されることを示しているもので紧るう。机 $\mathrm{Mg}$ 塭と

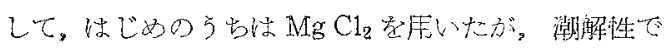
使用しにくいので，发とには $\mathrm{Mg} \mathrm{SO} 4$ 孝用いた。安主
恽に関しては差が女るよ5には㫕えない。

\section{2.フォージー残渣結合に及ぼす坸類の影響}

前項で行つた通りの些験を古いつァージ保存液で行 つた。筙 1 表の例について述ベると，2 5 月閒保存さ

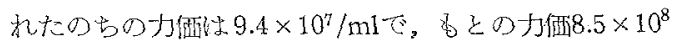
/ml の11パーセントに減少しているが，加温によりて

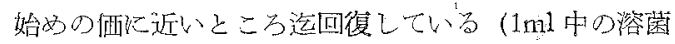
班数が94から 700 飞增加している)。再々述心゙るょう に，これ结残渣と結合することによつて不活化したつ アージか加温によつて離れて活性化したためで岁る。

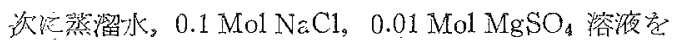

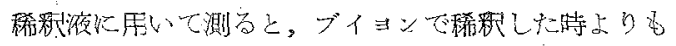
明方々多数の溶菌班が生じた。このことは残渣と結合 しているファージがっこれらの溶液中で解離したこと を示している。只， $0.01 \mathrm{Mol} \mathrm{Ca} \mathrm{Cl} 2$ 溶液学稀籸液に 用いた時には、ブイヨンの場含と略同数の溶菌斑が生 じた。しかし $\mathrm{CaCl}_{2}$ 溶液の場合にはブィヨンの時と 買り，稀播した液を加温してる溶菌略数が增していな

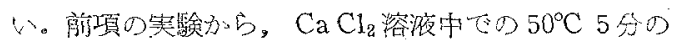
加温による不活化は30パーセン卜位で岁るから，をれ

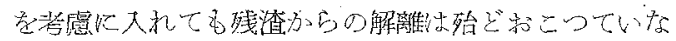


いといえる $(0.01 \mathrm{Mol} \mathrm{Ca} \mathrm{Cl} 2$ て稀彩した液を加温した

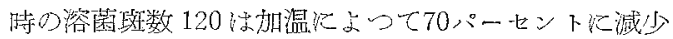

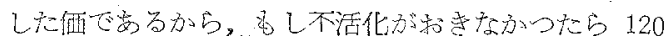
$\times \frac{100}{73}=164$ 伺の溶菌赎が生じた篦である。ブイヨン ではそれが700になつている。刎諭，残渣と結合して いるファージの姿定性は遊離のファージのそれとは異

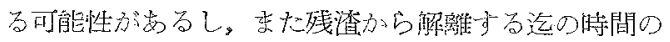

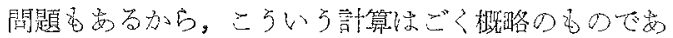
る). $\mathrm{Mg} \mathrm{SO}_{4}$ 溶液で稀㽗した液を加温した場合は，不

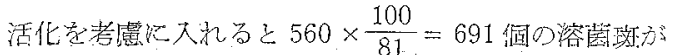
生じていることになり，略完全に解離がおこつたよう 侸われる。

こっでつくりたての力洒 $8.5 \times 10^{8} / \mathrm{ml}$ 党保存液 的の 全ファージ量とすると，残渣と結合しているファーシ 量は。全ファージ量の89パーセン下 $\left(\frac{850-94}{850} \times 100\right)$

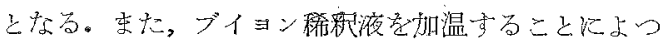
$て$, 結合ファージの80パーセジ $\left(\frac{700-94}{850-94} \times 100\right)$ か 解離したことになる。同榜の方法によつて，各溶液を

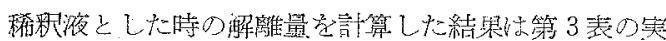
験 4 として記した。この表の他の 3 例は。別々につく られた いつのファージ保痒液で，今之同じ方法で行つ た实験の結染をまとめたものでかる。これらを通じて

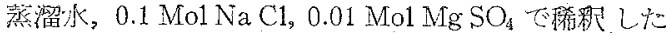

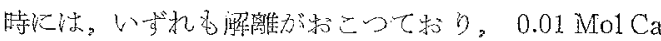

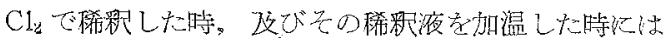

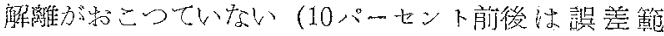

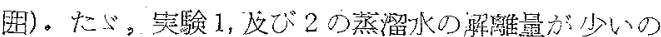

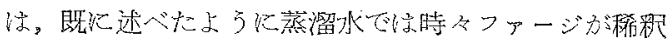

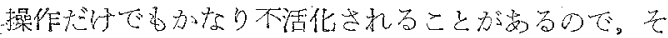
の影響ではないか子考光られる。合実験 1 では $\mathrm{Mg}$ $\mathrm{SO}_{4}$ の代りに $\mathrm{MgCl}_{2}$ が使用されている。この場合飞

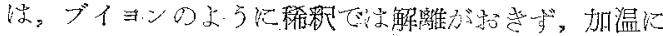

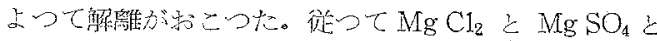
はかなり作用が暴つているようで岗るが，この点は試 薬の純度の間題る多るので，变らためて検討したいと 站光る。

\section{3. 加熱死菌に吸着したファージの溫度並びに篮類 の影響による解離}

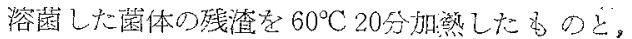
ファージが低温で絈含を执こし，加温並びに程類の影

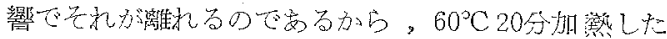

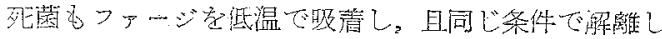

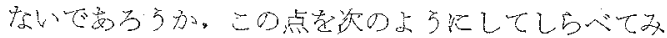

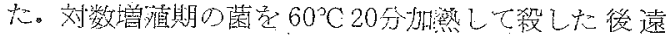
心し，新しいブイヨンに再浮游した後ファージ漼等加

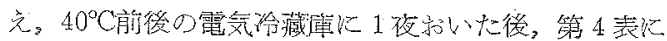
示すよらな種々の方法でファージ量を測定した。同表 の例飞ついて述べると，湿合液中のファージ量は始め

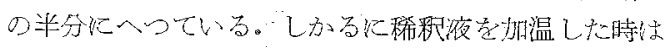
，溶菌趽数方格子との量に迄回復している。消失した

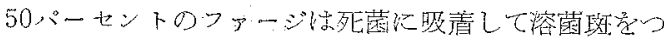
くれなくなつたためで岁り，加温尤つて溶菌斑数が

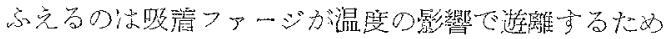
で苃ることは，刘照の死图を含まないファージ液ては中

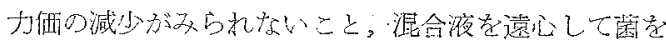

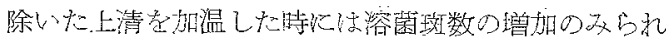
ないことから娟らかで岕るう。

加温によつて就れたファージ量は吸㾡ファージ舅の 90 パーセント飞岁たる $\left(\frac{81-42}{85-42} \times 100\right)$ 。混合液を0. $1 \mathrm{Mol} \mathrm{NaCl}$ 溶液で絺㽖した封は，稀罚しただけでや はり吸顔ファージの90パーセント迄が離れてしなら。

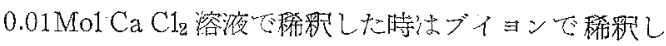
た洒と同じだから，吸着つァージ㤬全然離机ないわけ

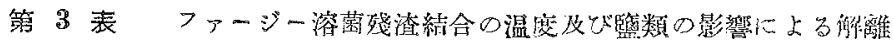

\begin{tabular}{|c|c|c|c|c|c|c|c|c|c|}
\hline \multirow{2}{*}{ 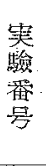 } & \multirow{2}{*}{ 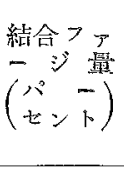 } & \multicolumn{8}{|c|}{ 解離ファージ量（絬合ファージ量に対するパーセント） } \\
\hline & & $\begin{array}{l}\text { ブイヨン } \\
\text { で稀 釈 }\end{array}$ & 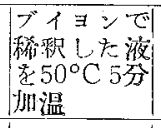 & $\begin{array}{l}\text { 蒸溜水て } \\
\text { 稀 釈 }\end{array}$ & $\begin{array}{l}0.1 \mathrm{Mol} \\
\mathrm{Na} \mathrm{Cl} \text { で } \\
\text { 稀 }\end{array}$ & $\begin{array}{l}0.01 \mathrm{Mol} \\
\mathrm{CaCl}_{2} \text { て } \\
\text { 稀 瀵 }\end{array}$ & 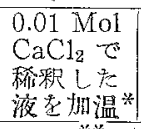 & $\begin{array}{l}0.01 \mathrm{Mol} \\
\mathrm{MgSo}_{4} \text { て } \\
\text { 稀 秎 }\end{array}$ & $\begin{array}{l}0.01 \mathrm{Mo} \\
\mathrm{MgSO}_{4} \text { で } \\
\text { 稀釈 Lた } \\
\text { 液老加温* }\end{array}$ \\
\hline 1 & 77 & 0 & 100 & 22 & 100 & 6.5 & $0^{* * * 1}$ & 0 & $83^{* * *}$ \\
\hline 2 & 62 & 0 & 84 & 39 & 89 & 13 & 1.6 & & \\
\hline 3 & 44 & 0 & 66 & 114 & 55 & 0 & 0 & 100 & 84 \\
\hline 4 & 89 & 0 & 80 & 92 & 74 & 0.8 & 3.4 & 51 & 62 \\
\hline
\end{tabular}

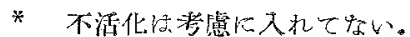

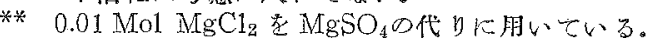




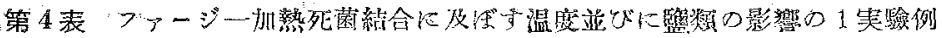

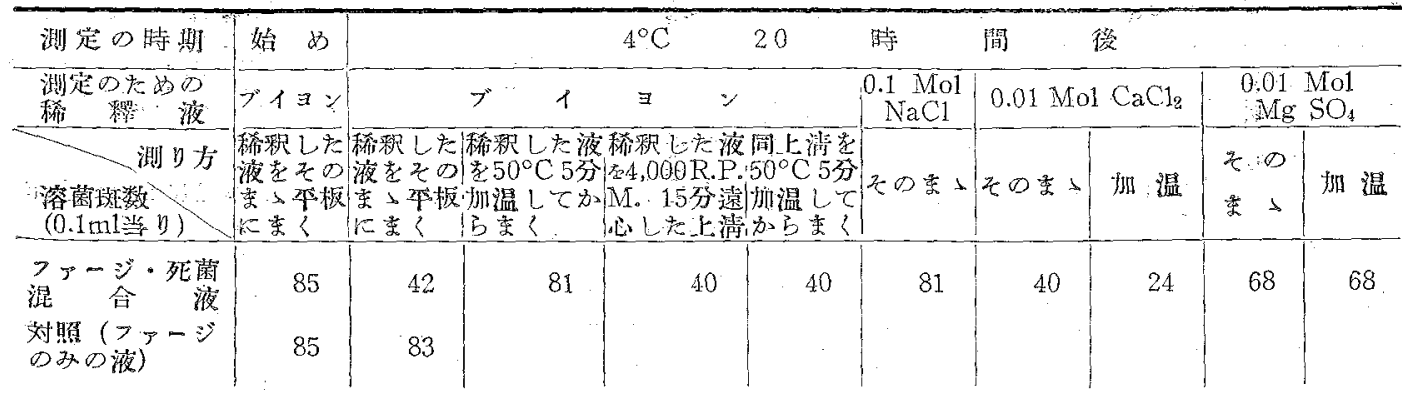

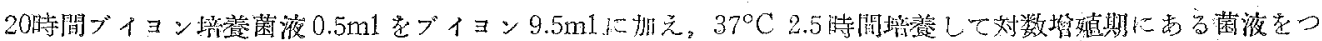

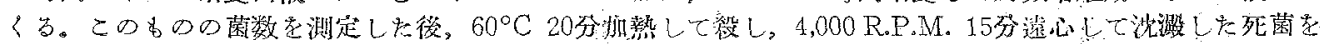

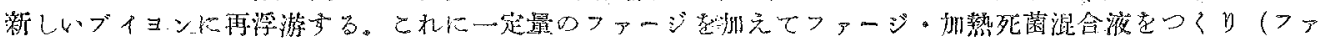

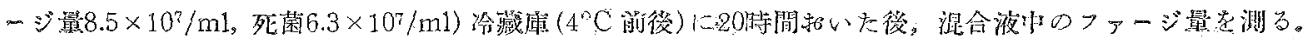

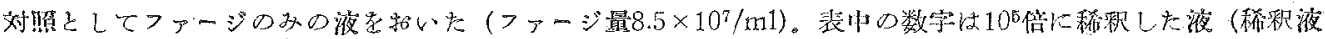

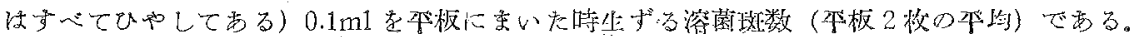

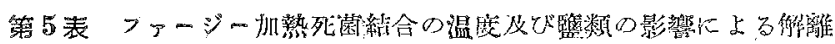

\begin{tabular}{|c|c|c|c|c|c|c|c|c|}
\hline \multirow[b]{2}{*}{ 実驗亩昘 } & \multirow{2}{*}{ 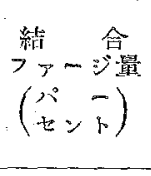 } & \multicolumn{7}{|c|}{ 解摛ファージ䰹（結合ファージ量に対するパーセント） } \\
\hline & & $\begin{array}{l}\text { ブイシン } \\
\text { で稀釈 }\end{array}$ & 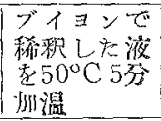 & $\begin{array}{l}0.1 \mathrm{Mol} \\
\text { Na C1 } \\
\text { 稀釈 }\end{array}$ & $\begin{array}{l}0.01 \mathrm{Mol} \\
\mathrm{CaCl}_{2} \circlearrowright \\
\text { 稀啋 }\end{array}$ & 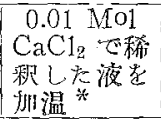 & $\begin{array}{c}0.01 \mathrm{Mol}^{2} \\
\mathrm{MgSO} \\
\text { で稀 䣋 }\end{array}$ & 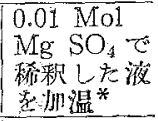 \\
\hline 1 & 52 & 0 & 70 & .80 & 0 & 0 & & \\
\hline 2 & 50 & 0 & 90 & 90 & 0 & 0 & 60 & 60 \\
\hline 3 & 77 & 0 & 58 & 65 & 0 & 0 & 58 & 58 \\
\hline
\end{tabular}

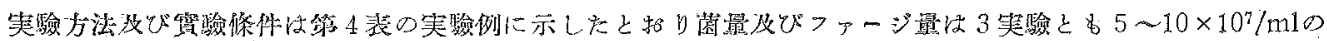
間にある。

*不涯化を考星に入れないで部算した。

で多る。尔た加温してもブイシンの期とば暴つてファ ージ姑解離しない。0.01 Mol Mg SC 4 溶液で署欺した 時炕吸竤ファージ量の60パーセントが離れた $\left(\frac{68-42}{85-42} \times 100\right)$ 。こ場合，加温して子それ以上踓

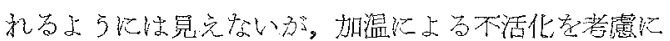
入れると略金䑁離れたのでななか子想像される

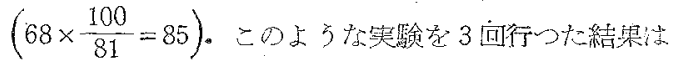

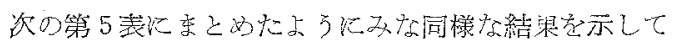

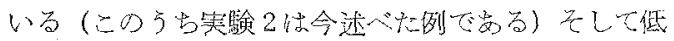

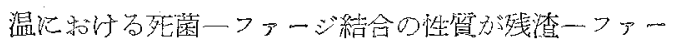
シ結合の性算と全く一致していること正等の結果加 ら明かでるる

\section{察}

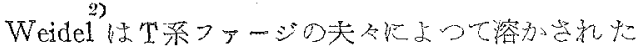
B菌の溶菌残湓に，溶かしたファージ以外の尔つア
ージを混合すると，加えられたファージのかなりの部

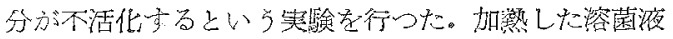
觉用いて子不活化分和きる己，部分的抵㧧菌て作つ た溶苜残渣（例えば B/2をT3で溶かした特できる溶

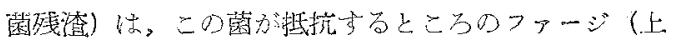
の例ならT2）を決して不活化しないことから，この

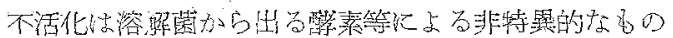

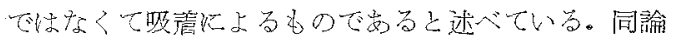

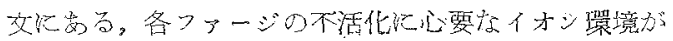
Puckのしらへたた吸青のそれと一致していることるま た。この不活化方残灌残されたファージレセプター による吸㦈尤よることの根扰となるら。

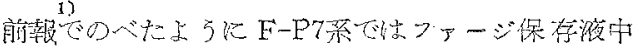
のファージが溶囷残稙へ結合することによつて段々之

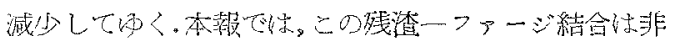
特黑的な結合て奴なくて，残渻上飞残されたファージ レセプターとファージの侍異的な結合で多ことを， 
この結合の解離の条仵を死菌ーファージ四着のそれと 比較することによつて証朝した。即ちフブイョンの中 で残管に結合したファージは蒸溜水，0.1 Mol Na C1, $0.01 \mathrm{Mol} \mathrm{MgSO} 4$ 溶液の中では離水て $0.01 \mathrm{Mol} \mathrm{Mg} \mathrm{Cl}_{2}$ $0.01 \mathrm{Mol} \mathrm{Ca} \mathrm{Cl} 2$ 溶液の中では離孔ない。またブイ イ ン皮び $\mathrm{Mg} \mathrm{Cl}_{2}$ 溶液の中では加温によつて結合か離れ るが、 $\mathrm{Ca} \mathrm{C1}$ 溶液の中では加温しても離机い。これ らの極るて特徵の变る条件がそつくり同じ形で, 死菌 と結合したファージの解離の条件となつている。

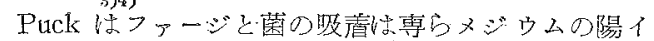
オンルよつて左右されること、陽不オンの穗類及び濃 度の及结す影響はつァージ化よつて夫及異ることを見 出した。要に，四着はこれらの陽イオンによつて陽性

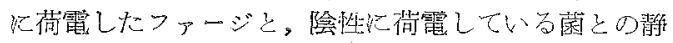
電的結合である。可逆的な，温度以支配されない

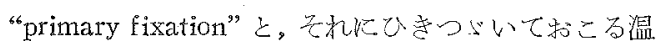

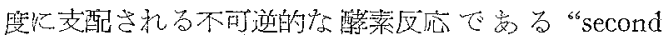
step”からなり，低温で吸着を行うことによつて “second step”加ら “primary fixation”定分離する こと成功した。吸着が “primary fixation” 比とど 宗っているような状態炕岕る時は、メジウムを吸着の 和こり光ない上らなイオン睘境に変党ることによつて 解離させることがでさる。

以上のような系ファージを用いてつくられた Puck の吸着像炕っで,上述の F-P7 系の現象む上 く説明される。即ち，残温或は死菌と〉ァージの結合 が可逆的で变ることは，醉素反庆で岁る“second

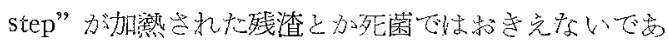

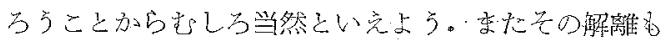
尃ら陽イオンの種類によつて支配されている。た心゙。 $\mathrm{Mg} \mathrm{Cl}_{2}$ と $\mathrm{Mg} \mathrm{SO}_{4}$ が解離に関して全く買つた影響を 与觉ることは興味がある。陰イオンが吸䒴。解離に影 響するはつきりしたデー夕はこ机までないが、ファー ジ及び第の複雜な吸着部位㑢イホンが介入して影響

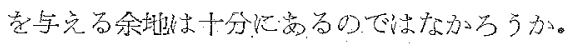

$\mathrm{Ca} \mathrm{Cl}_{2}$ 溶液の中ではブイヨンや $\mathrm{MgCl}_{2}$ 溶液の中と は異って，加温して子綪合つァージは活性化してこな い。このことは $\mathrm{CaCl}_{2}$ の中での結合は加温してひ解 離しないこと、即ち他のメジウム汇款好るよりるより

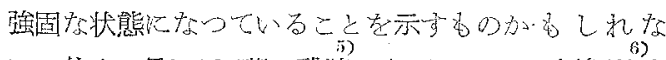

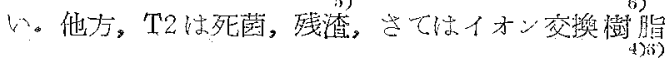
についた時でさ党。適当なイオン環境以光交机ば。 ファージ DNAの放出が行われ。ファージ梳不可逆的
に不活化される。勋つてP7ファージの上の現象 考考 克る時化。この上うな可能性も考慮してみる必要があ るで岗らう。

これらの問題之並えで,吸着の条作性解離の条作を

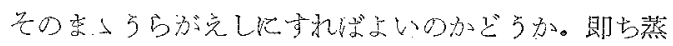
溜水や $0.1 \mathrm{Mol} \mathrm{Na} \mathrm{Cl}, 0.01 \mathrm{Mol} \mathrm{Mg} \mathrm{SO}$ の中でよ吸蔳 は标きず, $0.01 \mathrm{Mol} \mathrm{Mg} \mathrm{Cl}, 0.01 \mathrm{Mol} \mathrm{Ca} \mathrm{Cl} 2$ の中では

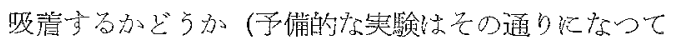
いる。即ちこのファージは吸萻に有機化合物の Co-

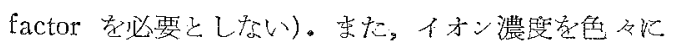
かえた時の影響はどうか。各イオン相互の間に拮抗作 用はないかといつた閏題が残つている。これらは今後 の研究に扔いてしらべてみたいと者觉ている。

\section{ををめ}

ファージ P7は、それが溶かした菌の残㴡と可逆的 な結合を寺る。この結合䛱。加温炕上り，なたメジウ

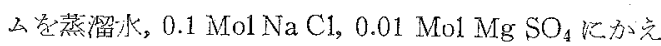
ることによって解離される。 $0.01 \mathrm{Mol} \mathrm{Mg} \mathrm{Cl}, 0.01$ $\mathrm{Mol} \mathrm{Ca} \mathrm{Cl} 2$ の中では解離しないが。 $\mathrm{Mg} \mathrm{Cl}_{2}$ の場合に はブイョンの時と同椂，加温札よつて解離される。加 䓡死菌之ファージの結合の解離の性質は，以上の残渣 一アージ結合の解離の性質と完全化一致するから， 残渣一ファージ結合怡残渣上儿残された菌のファージ レセプターとファージの間の特異的な結合で㚣ろう。 終りにのぞみ,川喜田愛郎教授の御指導, 教奚貣諸 见の御援助に深く感謝いたします。

\section{交献}

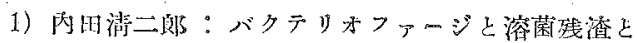
の可选的絓合. 1. 温度の影熋. Virtus, 5, 50-57, 1955 。 2) Weidel, W. : Further studies on the membrane of $E_{10}$ coli B. Ann. Inst. Pasteur, 84, 60-65, 1953. 3) Puck, T. T., Garen, A. and Cline, J. : The mechanism of virus attachment to host cells. I. The role of ions in the primary reaction. J. Exp. Med., 93, 65-88, 1951.4 4) Garen, A. and Puck, T. T.: The first two steps of the invasion of host cells by bacterial viruses II. J. Exx. Med., 94, 177-189, 1951. 5) Hershey, A. D. and Chase, $M$ : Independent functions of viral protein and nucleic acid in growth of bacteriophage. J. Gen. Physiol., 36, 39-56, 1952. 6) Puck, T. T. and Sagik, B.: Virts and cell interaction with ion exchangers. J. Exp. Med., 97, 807-820, 1953. 